\title{
Characterization of ethanol and 1,2-ethanediol adsorbates on platinized platinum with Fourier transform infrared spectroscopy and differential electrochemical mass spectrometry
}

Citation for published version (APA):

Gootzen, J. F. E., Visscher, W., \& Veen, van, J. A. R. (1996). Characterization of ethanol and 1,2-ethanediol adsorbates on platinized platinum with Fourier transform infrared spectroscopy and differential electrochemical mass spectrometry. Langmuir, 12(21), 5076-5082. https://doi.org/10.1021/la960103o

DOI:

10.1021/la960103o

Document status and date:

Published: 01/01/1996

Document Version:

Publisher's PDF, also known as Version of Record (includes final page, issue and volume numbers)

Please check the document version of this publication:

- A submitted manuscript is the version of the article upon submission and before peer-review. There can be important differences between the submitted version and the official published version of record. People interested in the research are advised to contact the author for the final version of the publication, or visit the $\mathrm{DOI}$ to the publisher's website.

- The final author version and the galley proof are versions of the publication after peer review.

- The final published version features the final layout of the paper including the volume, issue and page numbers.

Link to publication

\footnotetext{
General rights

- You may freely distribute the URL identifying the publication in the public portal. follow below link for the End User Agreement:

www.tue.nl/taverne

Take down policy

If you believe that this document breaches copyright please contact us at:

openaccess@tue.nl

providing details and we will investigate your claim.
}

Copyright and moral rights for the publications made accessible in the public portal are retained by the authors and/or other copyright owners and it is a condition of accessing publications that users recognise and abide by the legal requirements associated with these rights.

- Users may download and print one copy of any publication from the public portal for the purpose of private study or research.

- You may not further distribute the material or use it for any profit-making activity or commercial gain

If the publication is distributed under the terms of Article $25 \mathrm{fa}$ of the Dutch Copyright Act, indicated by the "Taverne" license above, please 


\title{
Characterization of Ethanol and 1,2-Ethanediol Adsorbates on Platinized Platinum with Fourier Transform Infrared Spectroscopy and Differential Electrochemical Mass Spectrometry
}

\author{
J . F. E. Gootzen,* W. Visscher, and J . A. R. van Veen \\ Department of I norganic Chemistry and Catalysis, Eindhoven University of Technology, \\ P.O. Box 513, $5600 \mathrm{MB}$ Eindhoven, The Netherlands \\ Received February 2, 1996. In Final Form: J uly 16, $1996^{\otimes}$
}

\begin{abstract}
The irreversible adsorption of ethanol and 1,2-ethanediol on platinized platinum has been studied with Fourier transform IR spectroscopy (FTIRS) and differential electrochemical mass spectrometry (DEMS) in perchloric acid electrolyte. The adsorption was found to be dissociative for both ethanol and 1,2ethanediol. During adsorption 1,2-ethanediol is completely dehydrogenated to adsorbed CO. For ethanol it was concluded that carbon species are formed in addition to adsorbed CO. Part of this residue is hydrogenated at low potential to methane.
\end{abstract}

\section{Introduction}

The electrochemical oxidations of 1,2-ethanediol and particularly ethanol on platinum are of considerable interest because of their role as model compounds for the study of the adsorption and electrooxidation behavior of organic species on platinum. Electrochemical studies can also provide useful information with respect to the platinum-catalyzed oxidation of al cohols with molecular oxygen in the liquid phase.

The electrooxidation of ethanol over platinum yields carbon di oxide, acetic acid, and acetaldehyde, ${ }^{1-6}$ as was found with spectroscopic methods. Several studies have been conducted to elucidate the structure of the irreversibly adsorbed species that are present on platinum after removal of the ethanol solution. The results are rather contradictory and can be divided into three categories. (i) Dissociation of the carbon-carbon bond occurs during adsorption, leading to the formation of adsorbed CO. This was suggested on the basis of differential el ectrochemical mass spectrometry (DEMS) ${ }^{7}$ and voltammetry. ${ }^{8-11}$ (ii) Dissociative as well as nondissociative adsorption was proposed on the basis of electrochemical thermal desorption mass spectrometry (ECTDMS) ${ }^{2}$ and F ourier transform infrared spectroscopy (FTIRS). ${ }^{12,13}$ (iii) Only nondissociativeadsorption occurs, leaving thecarbon-carbon bond intact. This conclusion was based on DEMS measurements. ${ }^{1}$

The formation of adsorbed $\mathrm{CO}$ was al so observed during bulk electrooxidation of ethanol with FTIR spectro-

\footnotetext{
${ }^{\otimes}$ Abstract published in AdvanceACS Abstracts, September 15, 1996.

(1) Willsau, J .; Heitbaum, J J . Electroanal. Chem. 1985, 194, 27. (2) Bittins-Cattaneo, B.; Wilhel m, S.; Cattaneo, E.; Buschmann, H. W.; Vielstich, W. Ber. Bunsen-Ges. Phys. Chem. 1988, 92, 1210.

(3) Leung, L.-W. H.; Chang, S.-C.; Weaver, M.J .J . Electroanal. Chem. 1989, 266, 317.

(4) I wasita, T.; Rasch, B.; Cattaneo, E.; Vielstich, W. Electrochim. Acta 1989, 34, 1073.

(5) Chang, S.-C.; Leung, L.-W. H.; Weaver, M. J . J . Phys. Chem. 1990, 94, 6013.

(6) Leung, L.-W. H.; Weaver, M. J . Langmuir 1990, 6, 323.

(7) Schmiemann, U.; Müller, U.; Baltruschat, H. Electrochim. Acta 1995, 40, 99.

(8) Cases, F.; López-Atalaya, M.; Vázquez, J. L.; Aldaz, A. J . Electroanal. Chem. 1990, 278, 433.

(9) Cases, F.; Morallon, E.; Vázquez, J . L.; Perez, J . M.; Aldaz, A.J . Electroanal. Chem. 1993, 350, 267.

(10) Cases, F.; Vázquez, J . L.; Perez, J . M.; Aldaz, A.J . Electroanal. Chem. 1991, 310, 403.

(11) Morin, M.-C.; Lamy, C.; Leger, J .-M.; Vázquez, J . L.; Aldaz, A. J. Electroanal. Chem. 1990, 283, 287.

(12) Holze, R. J . Electroanal. Chem. 1988, 246, 449.

(13) I wasita, T.; Pastor, E. Electrochim. Acta 1994, 39, 531.
}

scopy ${ }^{3-6,14}$ and potential modulated reflectance spectroscopy. ${ }^{15}$ Electrochemically modulated infrared spectroscopy (EMIRS) ${ }^{16}$ data suggested that in the presence of bulk ethanol dissociative as well as non-dissociative adsorption occurs.

The electrooxidation of 1,2-ethanediol over platinum gives glycolic acid and carbon dioxi de as bulk products in acid medium, as found with spectroscopic methods. ${ }^{17}$ The formation of adsorbed $\mathrm{CO}$ in the presence of bulk 1,2ethanediol has been observed with FTIRS 6,17 and electrochemically modulated infrared spectroscopy (EMIRS). ${ }^{18}$

It is remarkablethat the possiblepresence of $\mathrm{CH}_{x}$ groups next to adsorbed $\mathrm{CO}$ has only been mentioned by a few authors.7,9,15 In this paper we therefore investigate the irreversibly formed adsorbate of ethanol and 1,2-ethanediol with FTIR spectroscopy and DEMS to establish if adsorbed $\mathrm{CH}_{\mathrm{x}}$ groups are formed by dissociative adsorption. Also some experiments with dichlor omethaneand ethanewere conducted to study the possible formation of $\mathrm{CH}_{x}$ groups from these compounds.

\section{Experimental Section}

Infrared measurements were performed with a Biorad FTS 45A spectrometer, equipped with a liquid-nitrogen-cooled mercury cadmium telluride (MCT) detector. All spectra were recorded with $4 \mathrm{~cm}^{-1}$ resolution.

The electrochemical cell, made of glass, was placed on top of the sample room and was equipped with a $\mathrm{CaF}_{2}$ prism with $65^{\circ}$ beveled edges, to obtain a high reflection angle. The electrode consisted of a platinum disk of $9 \mathrm{~mm}$ diameter attached to a copper screw, by which it is connected to the electrode holder consisting of a copper interior embedded in PTFE. Theinfrared beam is focused on the electrode by one flat and one ellipsoidal mirror, with which the optimal spot size could be obtained. A polarizer is placed in thesample room to obtain p-polarized light.

DEMS measurements were performed with a Leybold QuadruvacPGA 100 mass spectrometer. The experimental setup is similar to the one described previously. ${ }^{19}$ The products were examined for $\mathrm{CO}_{2}\left(\mathrm{CO}_{2}+\mathrm{m} / \mathrm{e}=44\right), \mathrm{CH}_{4}\left(\mathrm{CH}_{3}{ }^{+} ; \mathrm{m} / \mathrm{e}=15\right)$ and $\mathrm{C}_{2} \mathrm{H}_{6}\left(\mathrm{C}_{2} \mathrm{H}_{4}+; \mathrm{m} / \mathrm{e}=28\right)$.

(14) Hitmi, H.; Belgsir, E. M.; Leger, J .-M.; Lamy, C.; Lezna, R. O Electrochim. Acta 1994, 39, 407.

(15) Caram, J. A.; Gutiérrez, C. J . Electroanal. Chem. 1992, 323, 213.

(16) Beden, B.; Morin, M.-C.; Hahn, F .; Lamy, C.J . Electroanal. Chem 1987, 229, 353.

(17) Christensen, P. A.; Hamnett, A. J . Electroanal. Chem. 1989, 260, 347.

(18) Hahn, F .; Beden, B.; Kadirgan, F .; Lamy, C.J . Electroanal . Chem 1987, 216, 169. $88,2$.

19) Wolter, O.; Heitbaum, J . Ber. Bunsen-Ges. Phys. Chem. 1984 


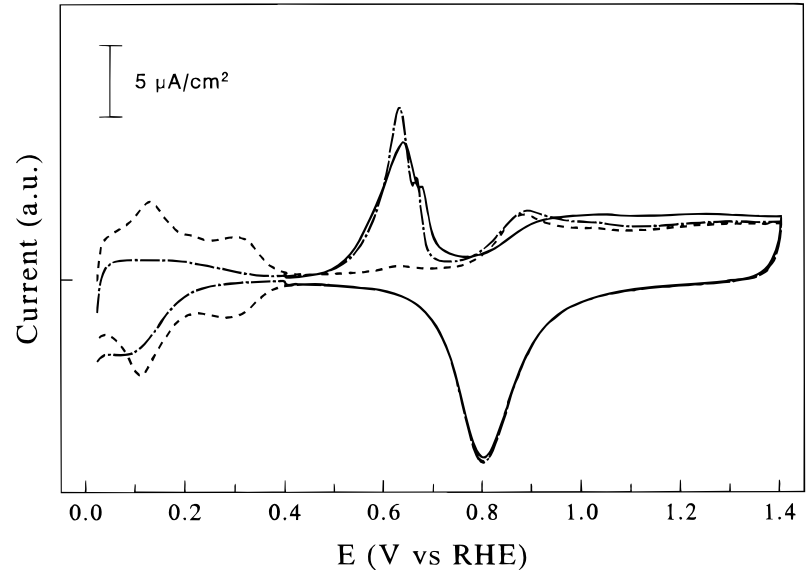

Figure 1. Cyclic voltammogram of ethanol adsorbate: (-) 'direct'oxidation; (---) 'indirect' oxidation; (- - -) blank. Adsorption at $0.4 \mathrm{~V}$ in $1 \mathrm{mM}$ ethanol. Electrolyte $0.5 \mathrm{M} \mathrm{HClO}_{4}$. Scan rate $5 \mathrm{mV} / \mathrm{s}$. Real area $177 \mathrm{~cm}^{2}$.

Electrochemical measurements were performed with an Autolab PGSTAT 20 computer-controlled potentiostat. A Hg/ $\mathrm{Hg}_{2} \mathrm{SO}_{4}$ electrodewas used as a referenceelectrode. All potentials will be referred to the reversible hydrogen electrode (RHE). All measurements were performed with platinized platinum that was prepared by electrodeposition in $0.05 \mathrm{M} \mathrm{H}_{2} \mathrm{PtCl}_{6}+0.01 \mathrm{M}$ $\mathrm{HCl}$ on smooth platinum. A deposition current of $10 \mathrm{~mA} / \mathrm{cm}^{2}$ was used on a substrate of $2.5 \mathrm{~cm}^{2}$. Before deposition the substrate was cleaned in a gas-oxygen flame at $1000{ }^{\circ} \mathrm{C}$. Platinized platinum was chosen, since the high area enables accurate assessment of both the charges involved in redox processes and the amount of product detected with the mass spectrometer. The electrode area was determined from the charge involved in the oxidation of the adsorbed hydrogen of a cyclic voltammogram obtained in $0.5 \mathrm{M} \mathrm{HClO}_{4}$.

Different electrodes were used for DEMS, FTIRS, and cyclic voltammetry, as indicated in thetext. Beforeeach measurement potential cycling between 0 and $1.5 \mathrm{~V}$ was carried out until a stablevol tammogram was obtained. Electrolytes were prepared using ultrapure water (18.2 $\mathrm{M} \Omega$ ) obtained with an Elga water purification system. In the infrared experiments $0.1 \mathrm{M} \mathrm{HClO}_{4}$ was used, and for cydic voltammetry and the DEMS measurements $0.5 \mathrm{M} \mathrm{HClO}_{4}$ was used. Oxygen was removed from the electrolyte with argon.

Adsorption was carried out at $0.4 \mathrm{~V}$ for $10 \mathrm{~min}$ in ethanol (Merck p.a.) or 1,2-ethanediol (Merck p.a.) solutions. In the case of dichloromethane (Merck p.a.) $100 \mu \mathrm{L}$ was added to the blank electrolyte. Ethane (Hoek Loos, purity 2.6) and CO (Hoek Loos, purity 4.7) wereadsorbed at $0.4 \mathrm{~V}$ for $10 \mathrm{~min}$ by bubbling through the solution. After adsorption the el ectrolyte was replaced by blank electrolyte, whilethe el ectrode was kept at the adsorption potential.

\section{Results}

Cyclic Voltammetry. A cyclic voltammogram of the ethanol adsorbate, formed at $0.40 \mathrm{~V}$ from $1 \mathrm{mM}$ electrolyte, is shown in Figure 1. The dashed curve represents the blank electrolyte. If the anodic scan is started at the adsorption potential, referred to as 'direct' oxidation, a peak is present at $0.641 \mathrm{~V}$ with a shoulder at $0.679 \mathrm{~V}$. This peak resembles theoxidation peak of adsor bed $\mathrm{CO} .20$ A broad wave is present in the oxide region that is not terminated at thereverse potential. Theamount of charge associated with oxidation of adsorbate in a second cycle is only very small. If the scan is started in the cathodic direction at the adsorption potential, a reduction wave is observed in the hydrogen region at potentials bel ow 0.20 $\mathrm{V}$. Thesubsequent anodicscan displays an oxidation peak that has narrowed and shifted to $0.633 \mathrm{~V}$ with a shoulder at $0.667 \mathrm{~V}$. The broad oxidation wave in the oxide region

(20) I anniello, R.; Schmidt, V. M.; Stimming, U.; Stumper,J .; Wallau, A. Electrochim. Acta 1994, 39, 1863.

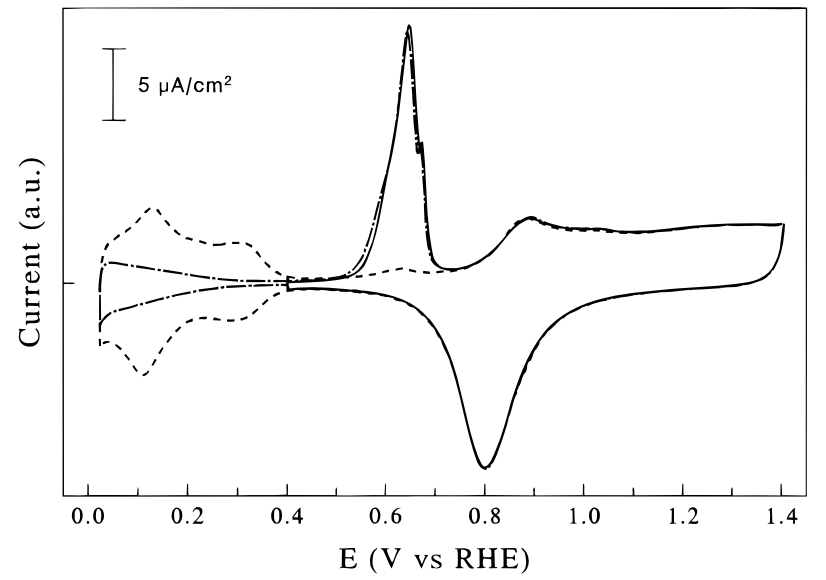

Figure 2. Cyclic voltammogram of 1,2-ethanediol adsorbate; $(-)$ 'direct' oxidation; (--) 'indirect' oxidation; (- - -) blank. Adsorption at $0.4 \mathrm{~V}$ in $1 \mathrm{mM}$ 1,2-ethanediol. Electrolyte $0.5 \mathrm{M}$ $\mathrm{HClO}_{4}$. Scan rate $5 \mathrm{mV} / \mathrm{s}$. Real area $177 \mathrm{~cm}^{2}$.

has decreased. This procedure is referred to as 'indirect' oxidation. The total oxidation charge, including the oxidation peak at low potential as well as the broad wave at higher potential, has decreased from $229 \mu \mathrm{C} / \mathrm{cm}^{2}$ for the 'direct' oxidation to $186 \mu \mathrm{C} / \mathrm{cm}^{2}$ for 'indirect' oxidation. The platinum area was established from the oxidation charge of adsorbed hydrogen in a cyclic voltammogram obtained in blank electrolyte.

The charge involved in the reduction, $\mathrm{Q}_{\text {red, }}$ can be determined by subtracting the charge involved in the anodic part of the scan bel ow $0.40 \mathrm{~V}$ from the charge invol ved in the cathodic part of the scan bel ow $0.40 \mathrm{~V}$. The cathodic part of the scan consists of both reduction of adsorbate and formation of adsorbed hydrogen from solution protons on uncovered platinum sites. Theanodic part of the scan only consists of oxidation of adsorbed hydrogen. Subtracting both values gives the charge involved in reduction; $Q_{\text {red }}=50 \mu \mathrm{C} / \mathrm{cm}^{2}$. The charge involved in the oxidation of adsorbed hydrogen has decreased to $20 \%$ of the value in the voltammogram of the blank electrol yte. This means that after reduction below $0.20 \mathrm{~V}$ still $80 \%$ of the platinum sites are covered with ethanol adsorbate. Note that the hydrogen liberated during adsorption by $\mathrm{C}-\mathrm{H}$ bond breaking is immediately oxidized to $\mathrm{H}^{+}$at the adsorption potential of $0.4 \mathrm{~V}$ and is thus not involved in the reactions described here.

The voltammogram of 1,2-ethanediol adsorbateformed at $0.4 \mathrm{~V}$ from $1 \mathrm{mM}$ 1,2-ethanediol shows only an oxidation wave at $0.643 \mathrm{~V}$ with a shoulder at $0.670 \mathrm{~V}$, as shown in Figure 2. Again the anodic peak resembles the oxidation of adsorbed $\mathrm{CO}$, but it is less broad than in the case of ethanol. In contrast with ethanol no reduction can be observed at low potential and no broad oxidation wave is present at high potential. The total oxidation charge is $218 \mu \mathrm{C} / \mathrm{cm}^{2}$, and from the anodic part of the scan below $0.40 \mathrm{~V}$ it follows that $87 \%$ of theplatinum sites are covered with 1,2-ethanediol adsorbate.

IR Experiments. Infrared spectra were obtained by subtracting the single-beam spectra measured before $\left(R_{0}\right)$ and after $\left(R_{1}\right)$ oxi dation of the adsorbate. The first singlebeam spectrum was obtained at the adsorption potential; the second was obtained at a potential of $0.75 \mathrm{~V}$ or at the adsorption potential after an excursion to $1.4 \mathrm{~V}$. The IR spectrum of the ethanol adsorbate is shown in Figure 3 and is given as $\Delta R / R_{0}\left(\Delta R=R_{0}-R_{1}\right)$. Besides thepositivegoing $\mathrm{ClO}_{4}^{-}$vibration at $1120 \mathrm{~cm}^{-1}, 21$ a negative-going 55.

(21) Corrigan, D. S.; Weaver, M.J . J . Electroanal. Chem. 1988, 239, 


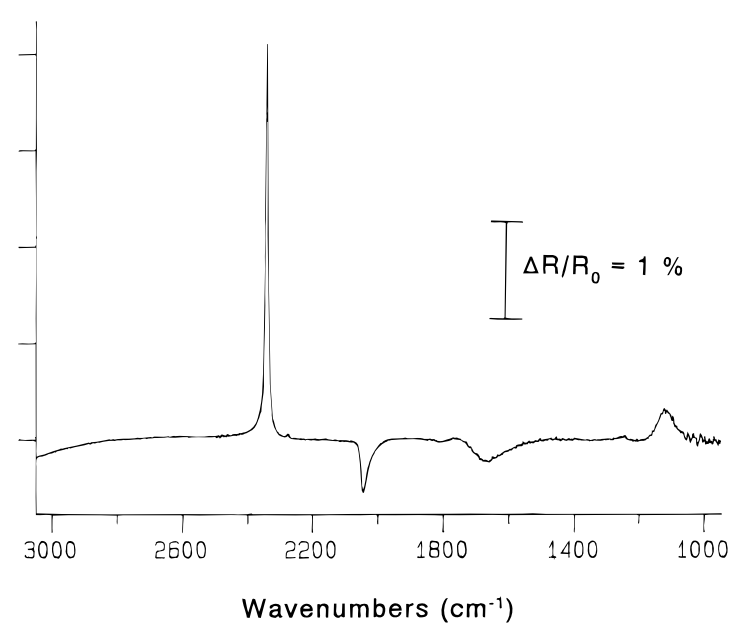

Figure 3. Infrared spectrum of ethanol adsorbate, obtained after adsorption at $0.4 \mathrm{~V}$ in $1 \mathrm{mM}$ ethanol. Electrolyte $0.1 \mathrm{M}$ $\mathrm{HClO}_{4}$. Resolution $4 \mathrm{~cm}^{-1}$. Reference potential $0.4 \mathrm{~V}$ after potential excursion to $1.4 \mathrm{~V}$.

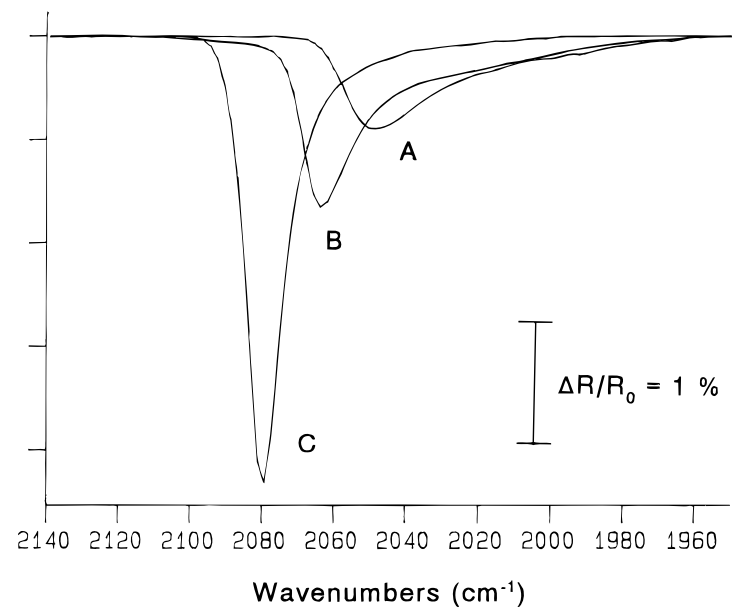

Figure 4. $\mathrm{CO}$ vibrations obtained after adsorption of $1 \mathrm{mM}$ ethanol (A), $1 \mathrm{mM}$ 1,2-ethanediol (B), and CO (C) in $0.1 \mathrm{M}$ $\mathrm{HClO}_{4}$. Resolution $4 \mathrm{~cm}^{-1}$. Reference potential $0.75 \mathrm{~V}$.

CO vibration at $2044 \mathrm{~cm}^{-1} 22$ and a positive-going band of $\mathrm{CO}_{2}$ at $2344 \mathrm{~cm}^{-1}$ are observed. The negative-going band at $1650 \mathrm{~cm}^{-1}$ is due to an uncompensated $\mathrm{H}_{2} \mathrm{O}$ bending mode. Upon magnification of the spectrum a small band is observed at $1805 \mathrm{~cm}^{-1}$, which can beassigned to bridge bonded $\mathrm{CO}^{22} \mathrm{No} \mathrm{C}-\mathrm{H}$ bands were observed within the detection limit of $0.01 \% \mathrm{~T}$ in the $\mathrm{C}-\mathrm{H}$ stretch region.

The IR spectrum of the 1,2-ethanediol adsorbate is virtually the same as those for the ethanol adsorbates. Figure 4 compares thespectra of adsorbed $\mathrm{CO}$ as obtained in the case of ethanol, 1,2-ethanediol, and gaseous CO. For both alcohols the amount of adsorbed $\mathrm{CO}$ formed during adsorption is lower than that for gaseous CO. Concurrently the vibrations are shifted to lower wavenumbers, as expected for lower coverages. The vibration frequency and integrated absorbance data are given in Table 1. The data suggest a considerable amount of adsor bed CO formed for both al cohols, with 1,2-ethanediol generating a higher amount than ethanol. The increase of the al cohol concentration from $1 \mathrm{mM}$ to $1 \mathrm{M}$ results in a small shift of the vibration frequency to higher wavenumbers. The small shift shows that the CO coverage increases only to a small extent in going from $1 \mathrm{mM}$ to 1

(22) Beden, B.; Bewick, A.; Kunimatsu, K.; Lamy, C. J . Electroanal. Chem. 1982, 142, 345.
Table 1. Vibration Frequencies and Integrated Absorbance of $\mathrm{CO}$ Obtained after the Adsorption of Ethanol, 1,2-Ethanediol, and $\mathrm{CO}^{\mathrm{a}}$

\begin{tabular}{|c|c|c|c|}
\hline & \multicolumn{2}{|c|}{ frequency $\left(\mathrm{cm}^{-1}\right)$} & \multirow{2}{*}{$\begin{array}{c}\text { integrated } \\
\text { Absorbance (au) } \\
1 \mathrm{mM}\end{array}$} \\
\hline & $1 \mathrm{mM}$ & $1 \mathrm{M}$ & \\
\hline ethanol & 2044 & 2048 & 0.43 \\
\hline 1,2-ethanediol & 2054 & 2060 & 0.64 \\
\hline CO & 2080 & 2080 & 1 \\
\hline
\end{tabular}

a The absorbance of $\mathrm{CO}$ is taken as unity.

M. It has indeed been found that at a concentration of 1 $\mathrm{mM}$ ethanol a nearly maximal adsorbate coverage is obtained.23

The calculation of the $\mathrm{CO}$ coverage from the integrated absorbance is admittedly difficult, since it is known from FTIRS studies in ultrahigh vacuum on singlecrystals ${ }^{24-28}$ that the integrated absorbance is not linearly related to the CO coverage. The relation between the integrated absorbance and the $\mathrm{CO}$ coverage for polycrystalline platinum would have to be established in separate experiments. Moreover, it is uncertain whether coadsorbates are present in the case of ethanol and 1,2ethanediol that might have some influence on the vibrational properties of $\mathrm{CO}$. Nevertheless we feel that it is possible to obtain the CO coverage with IR spectroscopy by approximation.

The formation of theadsorbed species from $1 \mathrm{M}$ ethanol was studied in situ with FTIRS by raising the electrode potential from 0.05 to $0.30 \mathrm{~V}$ and to $0.40 \mathrm{~V}$, recording a spectrum at each potential. At $0.05 \mathrm{~V}$ no chemi sorption of ethanol occurs, as shown by the absence of an anodic current when the ethanol solution is contacted with the platinum el ectrode; hence, the spectrum recorded at 0.05 $\checkmark$ can be used as a reference spectrum. The results are shown in Figure5. At $0.30 \mathrm{~V}$ adsorption of ethanol occurs, as indicated by the CO vibrations at $2040 \mathrm{~cm}^{-1}$ from linear $\mathrm{CO}$ and at $1845 \mathrm{~cm}^{-1}$ from bridge bonded CO. ${ }^{22}$ No other positive-going bands are observed. At $2984 \mathrm{~cm}^{-1}$ a negative-going $\mathrm{C}-\mathrm{H}$ band ${ }^{4}$ is observed, indicative of the disappearance of ethanol from the solution.

At $0.40 \mathrm{~V}$ the vibration at $2053 \mathrm{~cm}^{-1}$ implies further formation of linear CO. The bands that appear at 1717, 1395 , and $1285 \mathrm{~cm}^{-1}$ are indicative of acetic acid formation. ${ }^{4}$ Note that the acetic acid was accumulated in the thin layer during $5 \mathrm{~min}$, the time that was required for theadsorption of ethanol. At $0.40 \mathrm{~V}$ a positive-going band at $2343 \mathrm{~cm}^{-1}$ is observed that demonstrates the for mation of $\mathrm{CO}_{2}$. Again the disappearance of a $\mathrm{C}-\mathrm{H}$ vibration at $2984 \mathrm{~cm}^{-1}$ is observed.

Attempts to observe the hydrogenation products from the ethanol adsorbate formed at potentials below $0.20 \mathrm{~V}$ did not succeed; no $\mathrm{C}-\mathrm{H}$ vibrations or other vibrations could be found within the detection limit of $0.01 \% \mathrm{~T}$, probably due to the low concentration of hydrogenation products in the thin layer and a low absorptivity of the $\mathrm{C}-\mathrm{H}$ bands.

Differential E lectrochemical Mass Spectrometry (DEMS). Figure 6 shows the mass signals of $\mathrm{CO}_{2}$ for the oxidation and of $\mathrm{CH}_{4}$ for thereduction of ethanol adsorbate. When 'indirect' oxidation is performed, a small amount of methaneis detected at potentials bel ow $0.25 \mathrm{~V}$. Noethane

(23) Bruijn, de F. A.; Kuster, B. F. M.; Marin, G. B. Submitted toJ . Catal.

(24) Persson, B. N. J .; Ryberg, R. J . Phys. Rev. B 1981, 24, 6954.

(25) Crossley, A.; King, D. A. Surf. Sci. 1980, 95, 131

(26) Hayden, B. E.; Bradshaw, A. M. Surf. Sci. 1983, 125, 187.

(27) Hoge, D.; Tüshaus, M.; Schweizer, E.; Bradshaw, A. M. Chem. Phys. Lett. 1988, 151, 230.

(28) Hayden, B. E.; Kretzschmar, K.; Bradshaw, A. M.; Greenler, R. G. Surf. Sci. 1985, 149, 406. 

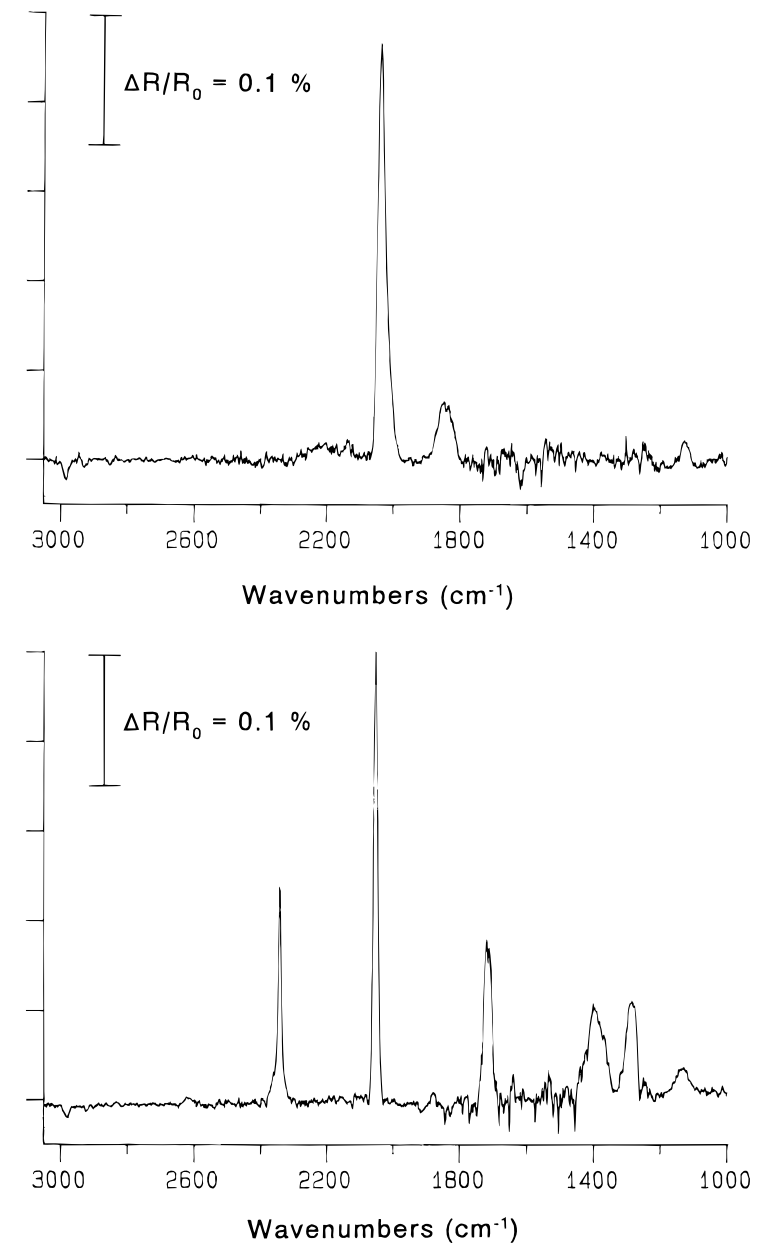

Figure 5. IR spectra obtained at $0.3 \mathrm{~V}$ (top spectrum) and 0.4 $V$ (bottom spectrum) in $1 \mathrm{M}$ ethanol. Resolution $4 \mathrm{~cm}^{-1}$. Reference potential $0.05 \mathrm{~V}$.

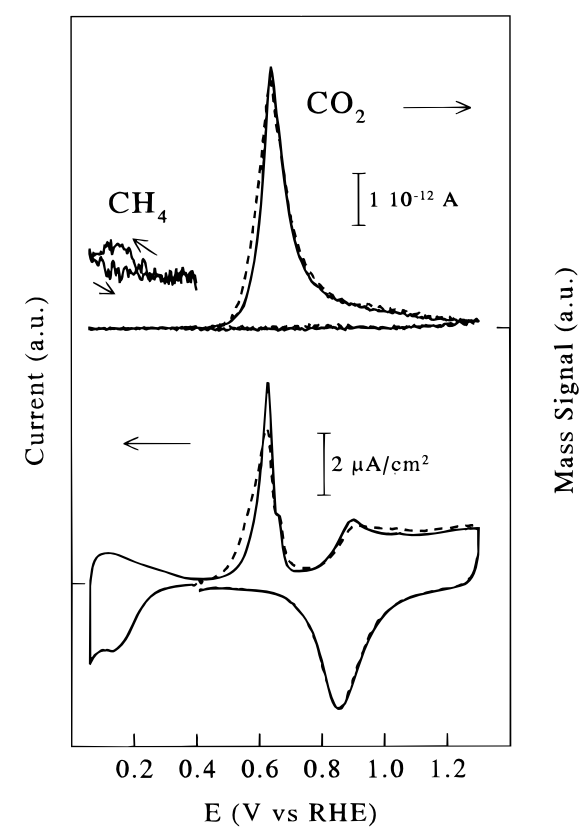

Figure 6. DEMS measurement obtained after adsorption at $0.4 \mathrm{~V}$ in $1 \mathrm{mM}$ ethanol. Electrolyte $0.5 \mathrm{M} \mathrm{HClO}_{4}$. 'Direct' (- - -) and 'indirect' oxidation (-). Scan rate $2 \mathrm{mV} / \mathrm{s} . \mathrm{m} / \mathrm{e}=44\left(\mathrm{CO}_{2}\right)$. $\mathrm{m} / \mathrm{e}=15\left(\mathrm{CH}_{4}\right)$. Real area $79 \mathrm{~cm}^{2}$.

could be detected. The amount of carbon di oxide formed in the 'indirect' oxidation is somewhat lower than that in the 'direct' oxidation. The number of electrons, $\mathrm{n}_{\mathrm{ox}}$, liberated per formed $\mathrm{CO}_{2}$ molecule can becalculated from

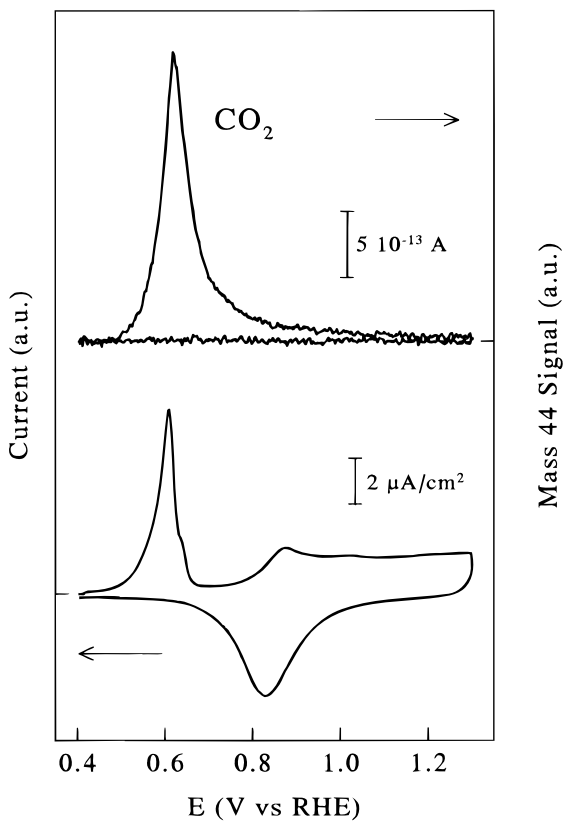

Figure 7. DEMS measurement obtained after adsorption at $0.4 \mathrm{~V}$ in $1 \mathrm{mM}$ 1,2-ethanediol. Electrolyte $0.5 \mathrm{M} \mathrm{HClO}_{4}$. Scan rate $2 \mathrm{mV} / \mathrm{s} . \mathrm{m} / \mathrm{e}=44\left(\mathrm{CO}_{2}\right)$. Real area $79 \mathrm{~cm}^{2}$.

the DEMS measurements. This requires calibration of the mass spectrometer for $\mathrm{CO}_{2}$; this is carried out by measuring the oxidation of adsorbed $\mathrm{CO}$ to $\mathrm{CO}_{2}$ in a reference experiment. This yields the calibration factor $\mathrm{K}_{\mathrm{CO}}$

$$
\mathrm{K}_{\mathrm{CO}}=\left(\frac{\mathrm{Q}_{\mathrm{ox}}}{\mathrm{Q}_{\text {mass }}}\right)_{\mathrm{CO}}
$$

where $Q_{o x}$ is the coulometric charge involved in the oxidation of $\mathrm{CO}$ to $\mathrm{CO}_{2}$ and $\mathrm{Q}_{\text {mass }}$ represents theintegrated mass current $\int \mathrm{i}_{\text {mass }} \mathrm{dt}$. The $\mathrm{n}_{\text {ox }}$ valuefor ethanol can then be obtained from the value $\mathrm{Q}_{o x} / \mathrm{Q}_{\text {mass }}$ measured for the alcohol oxidation according to

$$
\mathrm{n}_{\mathrm{ox}}=\left(\frac{\mathrm{Q}_{\mathrm{ox}}}{\mathrm{Q}_{\text {mass }}}\right)_{\text {ethanol }} \frac{1}{\mathrm{~K}_{\mathrm{co}}} \mathrm{n}_{\mathrm{ox}} \mathrm{co}
$$

with $\mathrm{n}_{\mathrm{ox}}{ }^{\mathrm{CO}}=2$ electrons per $\mathrm{CO}_{2}$ molecule. The $\mathrm{n}_{\mathrm{ox}}$ values were found to be 2.5 for the 'direct' oxidation of theethanol adsorbate and 2.2 for the 'indirect' oxidation. Themargin of error of these $n_{\text {ox }}$ values is estimated to be 0.1 .

Figure 7 shows the DEMS results for adsorbed 1,2ethanediol, which generates a higher amount of carbon dioxide than adsorbed ethanol. A value of 2.1 electrons per $\mathrm{CO}_{2}$ molecule was found. Nohydrogenation products such as methane or ethane could be detected during the cathodic scan.

DEMS results for the irreversible adsorbates of dichloromethane and ethane are shown in Figures 8 and 9. Because of thel ow solubility of both dichloromethaneand ethane only low adsorbate coverages werefound. The $n_{\text {ox }}$ values for the dichloromethane and ethane adsorbates were found to be respectively 3.2 and 3.3 electrons per $\mathrm{CO}_{2}$ molecule.

Coulometry. The charge $\mathrm{Q}_{\text {ads, }}$ liberated during the adsorption, was determined at $0.30 \mathrm{~V}$ with coulometry, sinceinfrared spectroscopy showed that nobulk oxidation products are formed at that potential. Adsorption was carried out in solutions of $1 \mathrm{mM}$ ethanol or 1,2-ethanediol for $10 \mathrm{~min}$. After adsorption the total charge released during direct oxidation of the adsorbate $\mathrm{Q}_{\mathrm{ox}}$ is determined 


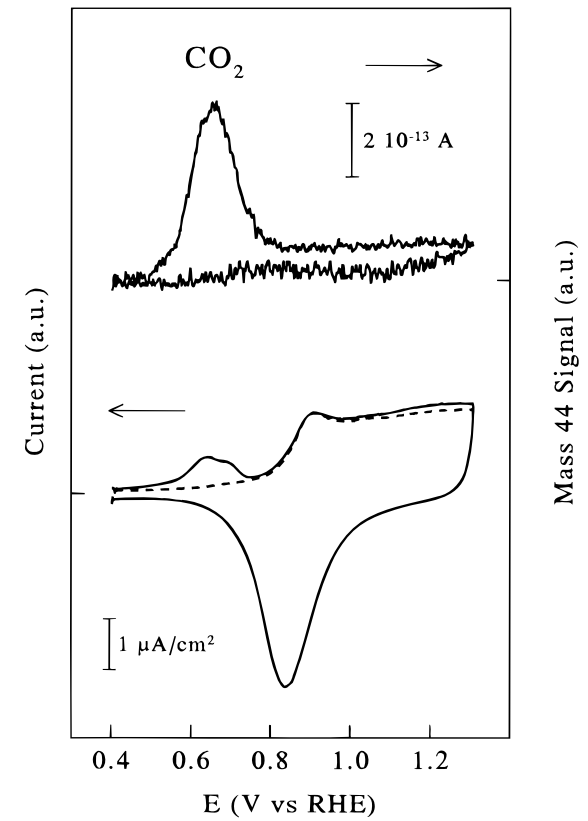

Figure 8. DEMS measurement obtained after adsorption of dichloromethane in $0.5 \mathrm{M} \mathrm{HClO}_{4}$. 'Direct' oxidation $(-)$ and blank (- - -). Scan rate $2 \mathrm{mV} / \mathrm{s} . \mathrm{m} / \mathrm{e}=44\left(\mathrm{CO}_{2}\right)$. Real area 79 $\mathrm{cm}^{2}$.

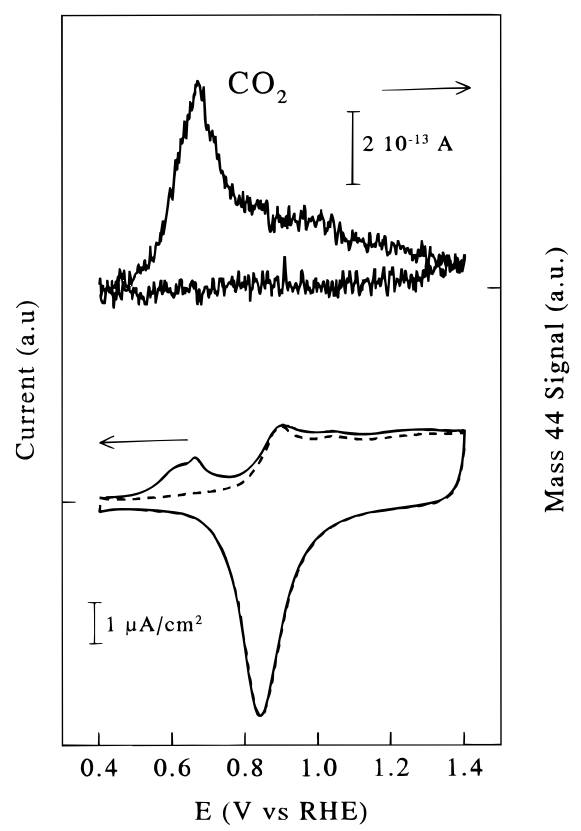

Figure 9. DEMS measurement obtained after adsorption of ethane in $0.5 \mathrm{M} \mathrm{HClO}_{4}$. 'Direct' oxidation (-) and blank (- - -). Scan rate $2 \mathrm{mV} / \mathrm{s} . \mathrm{m} / \mathrm{e}=44\left(\mathrm{CO}_{2}\right)$. Real area $79 \mathrm{~cm}^{2}$.

in a cyclic voltammogram. The ratio of the adsorption chargeand thetotal oxidation chargefor 'direct' oxidation $\mathrm{Q}_{\text {ads }} / \mathrm{Q}_{\mathrm{ox}}$ was 1.3 for ethanol and 1.5 for 1,2-ethanediol.

\section{Discussion}

1,2-Ethanediol. The observation of substantial amounts of adsorbed carbon monoxide with IR spectroscopy for 1,2-ethanediol indicates that this mol eculeadsorbs dissociatively on platinized platinum. The ratio $\mathrm{Q}_{\text {ads }} / \mathrm{Q}_{\mathrm{ox}}$ of 1.5 and the $\mathrm{n}_{\mathrm{ox}}$ value of 2.1 el ectrons per $\mathrm{CO}_{2}$ measured with DEMS clearly show that adsorbed CO is the only irreversible adsorbate that is formed according to

$$
\mathrm{HOCH}_{2} \mathrm{CH}_{2} \mathrm{OH} \rightarrow 2 \mathrm{CO}_{\text {ads }}+6 \mathrm{H}^{+}+6 \mathrm{e}
$$

The adsorbed carbon monoxide is oxidized at higher potential according to

$$
\mathrm{CO}_{\mathrm{ads}}+\mathrm{H}_{2} \mathrm{O} \rightarrow \mathrm{CO}_{2}+2 \mathrm{H}^{+}+2 \mathrm{e}
$$

This conclusi on is in agreement with previous reports for 1,2-ethanediol that observed $\mathrm{CO}$ in the presence of 1,2ethanediol in solution.6,17,18 However, no investigations have been carried out so far concerning the irreversible adsorbate in acid el ectrolyte.

From the oxidation charge $\mathrm{Q}_{\mathrm{ox}}$ in combination with $\mathrm{n}_{\mathrm{ox}}$ $=2.1$ a coverage of $0.52 \mathrm{CO}$ mol ecules per platinum atom can be calculated using the equation

$$
\theta=\frac{\mathrm{Q}_{\mathrm{ox}}}{\mathrm{n}_{\mathrm{ox}} \mathrm{Q}_{\mathrm{H}}{ }^{\circ}}
$$

where $\mathrm{QH}_{\mathrm{H}}{ }^{\circ}$ is the charge involved in the oxidation of adsorbed hydrogen in a voltammogram obtained in $0.5 \mathrm{M}$ $\mathrm{HClO}_{4}$. Theintegrated $\mathrm{CO}$ absorbances for 1,2-ethanediol and $\mathrm{CO}$ data in Table 1 are in agreement with the cal culated CO coverage of 0.52 for 1,2-ethanediol, given that the $\mathrm{CO}$ coverage for gaseous $\mathrm{CO}$ was found to be 0.7 in separate experiments. In our view the lower CO coverage for 1,2-ethanediol is connected to spatial requirements for thedissociation of $\mathrm{C}-\mathrm{C}$ and $\mathrm{C}-\mathrm{H}$ and $\mathrm{O}-\mathrm{H}$ bonds during adsorption. Energetically the breaking of the $\mathrm{C}-\mathrm{C}, \mathrm{C}-\mathrm{H}$, and $\mathrm{O}-\mathrm{H}$ bonds forms apparently no obstacle on the route to $\mathrm{CO}$ formation. The formation of the platinum-carbon bond and the multiple $\mathrm{C}-\mathrm{O}$ bond must be the driving force for this process.

Weencounter a discrepancy between cyclic voltammetry and IR spectroscopy when the hydrogen blocking due to $\mathrm{CO}$ adsorbates from 1,2-ethanediol is analyzed in terms of linear and bridge bonded $\mathrm{CO}$. Thehydrogen adsorption has decreased $87 \%$ of its original value, and so, on average, every CO molecule bl ocks $1.67(0.87 / 0.52)$ hydrogen sites. When it is assumed that linear adsorbed $\mathrm{CO}$ displaces one hydrogen atom and bridge bonded $\mathrm{CO}$ displaces two hydrogen atoms, the displacement ratio $\mathrm{H} / \mathrm{CO}=1.67$ indicates that $67 \%$ of the adsorbed $\mathrm{CO}$ is bridge bonded and $33 \%$ is linearly bonded. However our IR experiments reveal only a small fraction of bridge bonded CO whilethe majority is linear bonded $\mathrm{CO}$.

We must consider though that it has recently been shown for compressed CO adlayers on Pt(111) el ectrodes that in IR spectroscopy considerable intensity transfer from themultiplebonded $\mathrm{CO}$ vibration tothelinear bonded CO vibration can occur due to dynamic dipole-dipole coupling. ${ }^{29}$ The ratio of the integrated absorbances for linear and bridge bonded CO was a factor of four higher than expected on the basis of STM measurements. The phenomenon of intensity transfer has also been found in IR studies that were carried out in ultrahigh vacuum (UHV). ${ }^{24}$ However, even when thedifferent cross sections for linear and bridge bonded CO are included, our IR results are not in agreement with the cyclic voltammetry results that suggest that $67 \%$ is bridge bonded and $33 \%$ is linearly bonded $\mathrm{CO}$. Such a discrepancy between the IR and voltammetry results has also been noted in the case of adsorbed $\mathrm{CO}$ formed after $\mathrm{CO}_{2}$ reduction in phosphatebuffer at $\mathrm{pH}=6.8,{ }^{30}$ and the authors suggested the presence of IR insensitive species such as side-on adsorbed CO, a concept that has been introduced previously. ${ }^{31}$

(29) Villegas, I.; Weaver, M. J . J . Chem. Phys. 1994, 101, 1648.

(30) Taguchi, S.; Ohmori, T.; Aramata, A.; Enyo, M. J . Electroanal. Chem. 1994, 369, 199.

(31) I kezawa, Y.; Fujisawa, H.; Ishi, F. Surf. Sci. 1989, 218, 246. 
Another possible cause of error is the reconstruction of the surface, as reported for a $\mathrm{Pt}(110)$ single-crystal electrode. ${ }^{32}$ Theclean Pt(110)-(1×1) surface reconstructs partially intothePt(110)-( $2 \times 1)$ plane, which has a higher density of surface atoms. For the hydrogen adsorption $148 \mu \mathrm{C} / \mathrm{cm}^{2}$ is expected for the $(1 \times 1)$ surface and $222 \mu \mathrm{C}$ / $\mathrm{cm}^{2}$ is expected for the missing row reconstructed $(2 \times 1)$ surface. In the presence of adsorbed CO the surface reconstruction is lifted, ${ }^{33}$ and this can lead to thesituation that linear adsorbed CO apparently blocks 1.5 hydrogen atoms. However, in contrast with sulfuric acid, reconstruction is only observed to a minor degree in perchloric acid $^{32}$ and it can therefore not explain the discrepancy that we observed between voltammetry and I R spectroscopy.

Also the assumption that linear $\mathrm{CO}$ displaces one hydrogen atom and bridge bonded $\mathrm{CO}$ two hydrogen atoms might be somewhat oversimplified. Connected to this is the assumption that hydrogen atoms are adsorbed atop, although this has never been demonstrated. STM work has shown that even on $\mathrm{Pt}(111) \mathrm{CO}$ adlayers can have a complicated structurelike $(\sqrt{ } 19 \times \sqrt{ } 19) R 23.4^{\circ}-13 C O$ with a CO coverage of $0.68 .^{29}$ Part of the $\mathrm{CO}$ molecules are bonded asymmetrically in between atop and bridging geometries. The behavior of asymmetrically bonded CO in I R spectroscopy is typically linear, but it might possibly prevent the adsorption of two hydrogen atoms.

Ethanol. In the case of ethanol all data point in the direction of dissociative adorption as the only pathway leading to irreversible adsorbates, as was also found for 1,2-ethanediol. The substantial amount of $\mathrm{CO}$ observed with IR spectroscopy demonstrates that dissociative adsorption occurs. The integrated $\mathrm{CO}$ absorbance is only 30\% lower than that for 1,2-ethanediol, wheredissociative adsorption was demonstrated to be the only pathway, leading to $\theta_{\mathrm{CO}}=0.52$. Thefirst step in dissociativeethanol adsorption is probably the partial dehydrogenation of the molecule followed by dissociation of the $\mathrm{C}-\mathrm{C}$ bond, resulting in adsorbed $\mathrm{CO}$ and $\mathrm{CH}_{\mathrm{x}}$ according to

$$
\mathrm{C}_{2} \mathrm{H}_{5} \mathrm{OH} \rightarrow \mathrm{CO}_{\text {ads }}+\mathrm{CH}_{\mathrm{x}}+(6-x) \mathrm{H}^{+}+(6-x) e
$$

Theformation of methanein thereduction of theadsorbate layer shows that $\mathrm{CH}_{\mathrm{x}}$ species are present after adsorption, and the absence of ethane formation strongly suggests that nondissociated $\mathrm{C}_{2}$ species are not present. In a previous report a small amount of ethane was observed in addition to methane. ${ }^{13}$ The $\mathrm{n}_{\mathrm{ox}}$ value of 2.5 obtained for ethanol confirms that $\mathrm{CO}$ is not the only adsorbate and supports the claim that $\mathrm{CH}_{\times}$groups are present. Our conclusion that dissociative adsorption is the only adsorption pathway leading to irreversible adsorbates is in agreement with those of several others, ${ }^{7-11}$ as opposed to nondissociative adsorption as the only pathway. ${ }^{1} \mathrm{~A}$ combination of dissociativeand nondissociativeadsorption has also been suggested. 2,12,13

Only a few data are available on the adsorption of ethanol on platinum in ultrahigh vacuum. Thermal desorption spectrometry demonstrated that dissociation of adsorbed ethanol molecules in $\mathrm{CO}$ and $\mathrm{CH}_{\mathrm{x}}$ takes place at room temperatureon $\mathrm{Pt}(111),{ }^{35} \mathrm{Pd}(111),{ }^{36}$ and $\mathrm{Pd}(110){ }^{37}$ The $\mathrm{CH}_{\mathrm{x}}$ group is dehydrogenated to surface carbon on

(32) Armand, D.; Clavilier, J. J . Electroanal. Chem. 1989, 263, 109. (33) Chang, S.-C.; Weaver, M. J. Surf. Sci. 1990, 230, 222.

(34) Gao, P.; Lin, C.-H.; Shannon, C.; Salaita, G. N.; White, J . H.; Chaffins, S. A.; Hubbard, A. T. Langmuir 1991, 7, 1515.

(35) Zaera, F.; Hoffmann, H. J . Phys. Chem. 1991, 95, 6297.

(36) Zaera, F. Langmuir 1991, 7, 1998.

(37) Fairbrother, H.; Peng, X. D.; Viswanathan, R.; Stair, P. C.; Trenary, M.; Fan, J . Surf. Sci. Lett. 1993, 285, L 455. platinum, in contrast with palladium, wherethe $\mathrm{CH}_{\times}$group desorbed as $\mathrm{CH}_{4}$. These data show that the adsorption mechanism under ultrahigh vacuum conditions is very similar to that for adsorption in the liquid phase.

Beforeanalyzing the $n_{\mathrm{ox}}$ value of 2.5 found with DEMS, we will show that the data found with coul ometry are in good agreement with the DEMS results. FTIRS and DE MS have shown that $\mathrm{CO}_{2}$ is the only product formed in the oxidation of the irreversible adsorbate layer, whereas IR spectroscopy has shown that at theadsorption potential of $0.3 \mathrm{~V}$ used in the coulometry experiments no acetic acid is formed. This means that the obtained adsorption charge $\mathrm{Q}_{\text {ads }}$ can be completely ascribed to adsorption. Therefore, the $\mathrm{Q}_{\text {ads }} / \mathrm{Q}_{\mathrm{ox}}$ ratio of 1.3 found with coulometry suggests that of the 12 electrons liberated in thetotal oxidation of an ethanol moleculeto $\mathrm{CO}_{2}$ according to

$$
\mathrm{C}_{2} \mathrm{H}_{5} \mathrm{OH}+3 \mathrm{H}_{2} \mathrm{O} \rightarrow 2 \mathrm{CO}_{2}+12 \mathrm{H}^{+}+12 \mathrm{e}
$$

6.8 electrons are liberated during adsorption and 5.2 are liberated in the oxidation of the adsorbate. Since $2 \mathrm{CO}_{2}$ molecules are formed in the oxidation of a single ethanol adsorbate, 2.6 electrons per $\mathrm{CO}_{2}$ molecule are released. This value is in good agreement with the value of 2.5 found with DEMS.

Quantitative analysis of the $n_{\mathrm{ox}}$ value of 2.5 found with DEMS shows that a follow-up oxidation from $\mathrm{CH}_{x}$ to $\mathrm{CO}$ can occur after dissociation. Formation of equal amounts of $\mathrm{CO}$ and $\mathrm{CH}_{\mathrm{x}}$ during adsorption would result in $\mathrm{n}_{\mathrm{ox}}$ values between $3(x=0)$ and $4.5(x=3)$, according to

$$
\mathrm{n}_{\mathrm{ox}}=\frac{\mathrm{n}_{\mathrm{ox}, \mathrm{CO}}+\mathrm{n}_{\mathrm{ox}, \mathrm{CH}_{\mathrm{x}}}}{2}
$$

taking $\mathrm{n}_{\mathrm{ox}, \mathrm{CO}}=2$ and $\mathrm{n}_{\mathrm{ox}, \mathrm{CH}_{\mathrm{x}}}=(4+\mathrm{x})$. Since no methane was observed during the adsor ption, it must be concluded that the observed $n_{\mathrm{ox}}$ value of 2.5 does not originate from the removal of $\mathrm{CH}_{x}$ species during adsorption but from a follow-up reaction of $\mathrm{CH}_{x}$. This means that a fraction of the $\mathrm{CH}_{\mathrm{x}}$ species is oxidized to $\mathrm{CO}_{\text {ads; }}$ such a reaction mechanism has been proposed recently: ${ }^{7}$

$$
\mathrm{CH}_{\mathrm{x} \text { ads }}+\mathrm{H}_{2} \mathrm{O} \rightarrow \mathrm{CO}_{\text {ads }}+(2+\mathrm{x}) \mathrm{H}^{+}+(2+\mathrm{x}) \mathrm{e}
$$

The conclusion that $\mathrm{CH}_{\mathrm{x}}$ species can be oxidized to $\mathrm{CO}$ is supported by the DEMS data that we obtained for dichloromethane and ethane. The low $n_{0 x}$ values of 3.2 for dichloromethaneand 3.3 for ethanecan only becaused by the presence of adsorbates with low $n_{\text {ox }}$ values like $C O$. The $\mathrm{CH}_{3}$ group of ethanol and the $\mathrm{CH}_{2}$ group from dichloromethane seem to behave quite similarly upon adsorption, as follows from a quantitative analysis of the $\mathrm{n}_{\mathrm{ox}}$ number for ethanol. In the case of ethanol both the adsorbates formed from the $\mathrm{CH}_{3}$ and $\mathrm{CH}_{2} \mathrm{OH}$ groups contribute evenly to the $\mathrm{n}_{\mathrm{ox}}$ value of 2.5 , and both contributions can be calculated when it is assumed that the conversion of the $\mathrm{CH}_{2} \mathrm{OH}$ group to $\mathrm{CO}_{\text {ads }}$ is complete using

$$
\frac{\mathrm{n}_{\mathrm{ox}, \mathrm{CH}_{3}}+\mathrm{n}_{\mathrm{ox}, \mathrm{CH}_{2} \mathrm{OH}}}{2}=2.5
$$

It follows from this relation that, for the contribution of the adsorbatefrom the $\mathrm{CH}_{3}$ group $\mathrm{n}_{\mathrm{Ox}, \mathrm{CH}_{2} \mathrm{OH}}=3.0$ el ectrons per formed $\mathrm{CO}_{2}$ molecule. This number is close to the value of 3.2 found for the irreversible adsorbates from dichloromethane, demonstrating that the oxidation be 
havior of the $\mathrm{CH}_{3}$ group of ethanol is similar to that of the $\mathrm{CH}_{2}$ group from $\mathrm{CH}_{2} \mathrm{Cl}_{2}$.

Combining the $n_{\text {ox }}$ value found with DEMS with the voltammetry data gives the total adsorbate coverage as well as possible $\mathrm{CO}$ and $\mathrm{CH}_{\mathrm{x}}$ coverages. We will show that these data are in agreement with our IR data. It can becalculated from theoxidation charge $Q_{0 x}$ in combination with the $\mathrm{n}_{\mathrm{ox}}$ value of 2.5 that the adsorbate coverage is 0.44 per platinum atom, using therelation $\theta=\mathrm{Q}_{o x} /\left(\mathrm{n}_{\mathrm{ox}} \mathrm{Q}_{\mathrm{H}}{ }^{\circ}\right)$. This coverage is somewhat lower than that for 1,2ethanediol, where $0.52 \mathrm{CO}$ mol ecules per platinum atom were found. The exact adsorbate composition can be calculated as well from the fractional contribution of the $\mathrm{CO}$ and $\mathrm{CH}_{\mathrm{x}}$ groups to the $\mathrm{n}_{\mathrm{ox}}$ value of 2.5 , using the relations

$$
\begin{gathered}
\frac{\theta_{\mathrm{CO}}}{\theta_{\mathrm{CO}}+\theta_{\mathrm{CH}_{x}}} \mathrm{n}_{\mathrm{ox}, \mathrm{CO}}+\frac{\theta_{\mathrm{CH}_{\mathrm{x}}}}{\theta_{\mathrm{CO}}+\theta_{\mathrm{CH}_{\mathrm{x}}}} \mathrm{n}_{\mathrm{ox}, \mathrm{CH}}=2.5 \\
\theta_{\mathrm{CO}}+\theta_{\mathrm{CH}_{\mathrm{x}}}=0.44
\end{gathered}
$$

with $\mathrm{n}_{\mathrm{ox}, \mathrm{CO}}=2$ and $\mathrm{n}_{\mathrm{ox}, \mathrm{CH}_{\mathrm{x}}}=(4+\mathrm{x})$. Fromthese equations it follows that in the case of $C$ as the coadsorbate $(x=0)$ the $\mathrm{CO}$ coverage is 0.33 and for $\mathrm{CH}_{3}$ as the coadsorbate the CO coverage is 0.40 . This result is in good agreement with the IR data presented in Table 1, which show a $33 \%$ lower integrated CO absorption for ethanol with respect to 1,2-ethanediol, for which $\theta_{\mathrm{CO}}$ was established as 0.52 .

Evaluation of the charges involved in thereduction and in the 'direct' and 'indirect' oxidation of ethanol in view of the dissociative reaction mechanism gives information on the oxidation state of the $\mathrm{CH}_{\mathrm{x}}$ species. As a result of the reduction of the adsorbate, the charge $\mathrm{Q}_{\mathrm{ox}}$ invol ved in the 'indirect' oxidation is lower than the charge $Q_{0 x}$ for the 'direct' oxidation. Theratio $\mathrm{Q}_{\mathrm{red}} / \Delta \mathrm{Q}_{\mathrm{ox}}$ of 1.2 suggests that the hydrogenated species is a carbon species with the average oxidation state zero, since in the reduction as well as the oxidation of elemental carbon four electrons are involved according to

$$
\begin{gathered}
\mathrm{C}+4 \mathrm{H}^{+}+4 \mathrm{e} \rightarrow \mathrm{CH}_{4} \\
\mathrm{C}+2 \mathrm{H}_{2} \mathrm{O} \rightarrow \mathrm{CO}_{2}+4 \mathrm{H}^{+}+4 \mathrm{e}
\end{gathered}
$$

It is unlikely that ethanol generates $\mathrm{COH}$ species that contribute to hydrogenation at low potentials, since no evidence was found for such a species in the case of 1,2ethanediol. Therefore it seems appropriate to conclude that elemental carbon is the only species that is hydrogenated to methane at low potentials. It must be noted that onl y a fraction of the carbon residue is hydrogenated. No firm conclusions can be drawn on the nature of the carbon residues that are insensitive to hydrogenation. The reason for the partial hydrogenation might be the occurrence of carbon islands on the surface that are insensitivetoward hydrogenation. Elemental carbon can beformed through further dehydrogenation of $\mathrm{CH}_{\mathrm{x}}$ species according to

$$
\mathrm{CH}_{\mathrm{x}} \rightarrow \mathrm{C}+\mathrm{xH}^{+}+\mathrm{xe}
$$

The conclusion that carbon atoms are formed is in accordance with the absence of $\mathrm{C}-\mathrm{H}$ vibrations in the IR spectrum in Figure 3 within the detection limit of $0.01 \% \mathrm{~T}$. In contrast with our measurements, $\mathrm{C}-\mathrm{H}$ vibrations were observed with $\mathrm{FTIRS}^{13}$ at 2960,2920 , and $2850 \mathrm{~cm}^{-1}$ with intensities of approximately $0.1 \% \mathrm{~T}$ that were ascribed to an adsorbed ethoxy species. Electron energy loss spectroscopy (EELS) also observed $\mathrm{C}-\mathrm{H}$ vibrations after transfer of the electrode to UHV. ${ }^{34}$

IR and thermal desorption studies of $\mathrm{CH}_{3}$ adspecies on $\mathrm{Pt}(111)$ in UHV support our conclusion that complete dehydrogenation of the $\mathrm{CH}_{x}$ species has occurred. IR studies have shown that adsorbed $\mathrm{CH}_{3}$ moieties on Pt(111) at $150 \mathrm{~K}$ are characterized by a single $\mathrm{C}-\mathrm{H}$ band at $2885 \mathrm{~cm}^{-1}$ of approximately $0.07 \% \mathrm{~T}$ at saturation coverage. ${ }^{38-40}$ Adsorbed $\mathrm{CH}_{3}$ species are subject to dehydrogenation at temperatures above $230 \mathrm{~K}$, and the $\mathrm{C}-\mathrm{H}$ stretch vibration at $2885 \mathrm{~cm}^{-1}$ in the IR spectrum has completely di sappeared after increasing the temperature to $300 \mathrm{~K}, 38-42$ indicative of complete dehydrogenation to carbon species. In accordance with this, complete dehydrogenation of adsorbed $\mathrm{CH}_{2}$ species formed from $\mathrm{CH}_{2} \mathrm{Cl}_{2}$ is observed on $\mathrm{Pd}(100)$ at room temperature ${ }^{43}$ It is characteristic for UHV experiments that adsorbed hydrogen formed in dehydrogenation of methyl fragments desorbs in the temperature regi on $280-350 \mathrm{~K}$, indicating that at room temperature some adsorbed hydrogen can be present. ${ }^{38}$ However, in our el ectrochemical adsorption experiments at $0.4 \mathrm{~V}$ dissociation of $\mathrm{C}-\mathrm{H}$ bonds is accompanied by oxidation of the hydrogen atom toa proton. The energy involved in the oxidation might generate an extra driving forcefor $\mathrm{C}-\mathrm{H}$ dissociation, favoring complete dehydrogenation of $\mathrm{CH}_{\mathrm{x}}$ species to carbon.

\section{Conclusions}

In the present study we have shown on the basis of FTIRS and DEMS measurements that both 1,2-ethanediol and ethanol adsorb dissociatively. During adsorption 1,2ethanediol is completely dehydrogenated to $\mathrm{CO}_{\text {ads. }}$ In the adsorption of ethanol the alcohol group is completely dehydrogenated to $\mathrm{CO}_{\text {ads }}$, the methyl group is partially oxidized to $\mathrm{CO}_{\mathrm{ads}}$ and partially dehydrogenated to a hydrogenable $\mathrm{C}_{\text {ads }}$ species, and a small fraction is formed that is insensitive toward hydrogenation. The nature of thelatter is unknown. Infrared spectroscopy has revealed that for both ethanol and 1,2-ethanediol $\mathrm{CO}_{\text {ads }}$ is adsorbed mainly linear, in contrast with voltammetry results that suggest the presence of Iarge amounts of bridge bonded CO.

\section{LA9601030} 181 .

(38) Sexton, B. A.; Rendulic, K. D.; Huges, A. E. Surf. Sci. 1982, 121

(39) Davis, J . L.; Barteau, M. A. Surf. Sci. 1987, 187, 387.

(40) Shekhar, R.; Barteau, M. A. Catal. Lett. 1995, 31, 221.

(41) Fan, J .; Trenary, M. Langmuir 1994, 10, 3649.

(42) French, C.; Harrison, I. Surf. Sci. 1995, 342, 85.

(43) Wang, Y.-N.; Marcor, J . A.; Simmons, G. W.; Klier, K. J . Phys. Chem. 1990, 94, 7597. 